\title{
Impact of the Emergency Finance Scheme (EFS) for Architects During the COVID-19 Pandemic
}

\author{
Masud Ur Rashid* \\ Associate Professor, Department of Architecture, Southeast University, Dhaka, Bangladesh
}

Submission: April 15, 2021; Published: May 10, 2021

"Corresponding author: Masud Ur Rashid, Associate Professor, Department of Architecture, Southeast University, Dhaka, Bangladesh Treasurer, Institute of Architects Bangladesh

\begin{abstract}
The financial crisis caused by the COVID-19 pandemic has almost devastated a section of architects of Bangladesh engaged in the architectural profession and relatively new architectural firms. Institute of Architects Bangladesh (IAB) initiated a scheme titles 'Emergency Finance Scheme (EFS)' for the members who are facing difficulties to bear their livelihood for time being. From this scheme, a member can avail of an interest-free loan. The fund is created by the refundable contribution from well-off members who are agreed to contribute by giving an interest-free loan to IAB. This article finds the response of this scheme by the architects and produces an analysis of the beneficiaries. The research is carried out along with quantitative data triangulation using a qualitative research approach. Surveys with semi-structured questionnaires on all the beneficiary architects were taken place. It is found by this study that male architects below 40 years of age who are married and having kids and are obliged to support their parents are the most distressed group in terms of financial crisis due to the COVID-19 pandemic.
\end{abstract}

Keywords: COVID-19, Pandemic; Institute of Architects Bangladesh; Emergency Finance Scheme; Architects of Bangladesh

\section{Introduction}

The COVID-19 pandemic has caused an unprecedented human and health crisis. At this point, there is great uncertainty about its severity and length. Fear of the coronavirus disease (COVID-19) has spread around the world. The national economy is shut down, and self-quarantining of millions of people has become the "new normal" [1]. The economic system has already felt a dramatic impact, and further intensification of the crisis could affect global financial stability [2]. COVID-19 has rapidly affected our day to day life, businesses, disrupted world trade and movements. The major impact of COVID-19 in economic categories are- slowing of the manufacturing of essential goods; disrupt the supply chain of the product; losses in national and international business; poor cash flow in the market and significant slowing down in the revenue growth [3]. This COVID-19 has affected the sources of supply and affects the global economy [4].

Through quick administrative action and raising awareness for individuals on social-distancing, stringent steps were taken to manage the spread of the disease by canceling thousands of locations that involved social gathering including offices, classrooms, reception centers, clubs, transport services, and travel restrictions, leaving many countries in complete lockdown [5].
Like many other countries, in Bangladesh, many business entities, as well as the professional arena, faced an economic crisis.

Institute of Architects Bangladesh (IAB) is the National Institute for professional architects and apex regulatory body for the architectural profession [6]. IAB is responsible for the regulations of architects' professional practices, development of building codes and working as the official community of architects looking after the welfare of the professionals. IAB is a professional institution to safeguard, promote and develop the profession of architecture in Bangladesh. The members of IAB are morally bound to practice the profession according to rules, regulations and ethics established by the IAB. The Institute is run by a Fifteenmember Executive Council that the members elect for a two years' term [7]. IAB is the licensing authority for its members which gives the signatory power to design buildings in Bangladesh [8]. For the professional architects, it has three categories of memberships, e.g. Associate Member (young and junior architects), Member and Fellow (member with 20 years of experience).

Institute of Architects Bangladesh (IAB) is an institute of more than 4500 members [7]. All of them are not capable enough to cope-off with the financial crises raised by the COVID-19. Some 
of them have already faced difficulties to bear their livelihood for time being. On the other hand, many well-off members could and wanted to contribute to this crisis period [9].

IAB initiated a scheme titles 'Emergency Finance Scheme (EFS)' for its members. This scheme is to make an arrangement where a donor or a contributor member can help other members, termed as beneficiaries, who face difficulties for their living during or right after the COVID-19 crisis. As a professional body, this is an initiative to support its' members during the global pandemic [7]. In this scheme, one can get a short-term loan without any kind of interest or service charge. IAB is doing this scheme as a part of its social responsibility towards the members.

\section{Methodology}

The main objective of this article is to analyze the Emergency Finance Scheme (EFS) that was launched by the Institute of Architects Bangladesh (IAB) for its members and the impact of this scheme on the COVID-19 crisis.

The study is done through a qualitative research approach along with quantitative data triangulation. This study is based on both primary and secondary data. Primary data has been collected through the semi-structured questionnaire survey of the beneficiaries. Secondary sources of data are the EFS related publications and notices by IAB and the IAB database. Also, some interviews of IAB officials are taken as sources of data.
A semi-structured questionnaire survey has been conducted among 16 architects who have taken a loan from the EFS. Their professional and demographic data are taken from the IAB membership portal where all the professional, demographic and academic information has been stored. These are accessed with the permission of IAB management. The application forms and other relevant documents that the applicants submitted for sanctioning of loan, are analyzed to collect the personal, family and economic information of the beneficiaries. Interviews and discussions with IAB office staff and members of the EFS Board of management took place to get the opinions and views about the execution process of this scheme.

After collecting all the information, they are stored in an Excel datasheet and analyzed by Excel and SPSS (Statistical Package for the Social Sciences) software to come up with the findings through statistical data analysis. Most of the interviews, questionnaire surveys and discussions are conducted through online or telecommunication. Resources used as secondary data are supplied by the IAB office or available at the website This EFS is the first of its kind, so the author did not receive much published reference to make a comparative background study.

\section{Execution Process of EFS}

The total projected timeline of the scheme was approximately two years. The following figure (Figure 1) shows the timeline along with the different steps of the scheme.

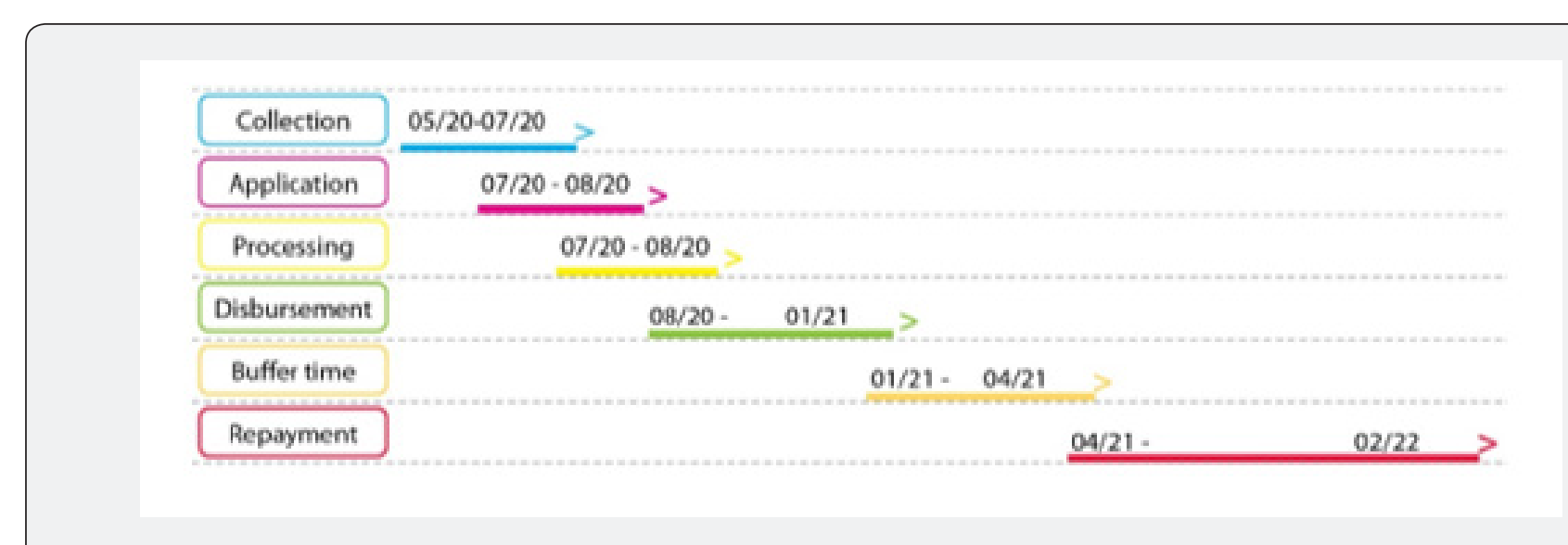

Figure 1: Estimated timeline of the scheme ( $\mathrm{mm} / \mathrm{yy})$.

The process to work with this scheme would be executed by the following steps:

\section{Step 1: Sourcing of Fund}

The major fund of EFS would be formed through a. Donation and $b$. Refundable Contribution from individuals, business entities and institutions with the following details:

Donation from individuals, business entities and institutions:
Any individual, business entity or institute from home or abroad can donate money of any amount if he/she supports the objective of the scheme.

Refundable Contribution (RC) from an individual, business entity or institute, to be termed as the Contributor as per the following clauses:

a) The minimum amount of RC is 50,000.00 BDT or a multiple of it. 
b) Refund to the Contributor will begin after a minimum of nine months from the date of $\mathrm{RC}$ received. The refund can begin after 12 months if the Contributor agrees.

c) IAB will refund the amount in 5 to 10 numbers Equal Monthly Installments (EMI) upon the understanding with the Contributor.

d) There will be a bi-party agreement between IAB and the Contributor mentioning the repayment policy. e) The Contributor will not get any monetary profit from the money. It will be considered as a benevolent act and will be recognized as a contribution to the profession.

All contributions must be recommended by the EFS Board of Management and approved by the Executive Council of IAB. Besides the donation and contribution, a portion of IAB Benevolent Fund (IAB's own reserve fund for its members benevolent) may also be used for the EFS scheme (Figure 2).

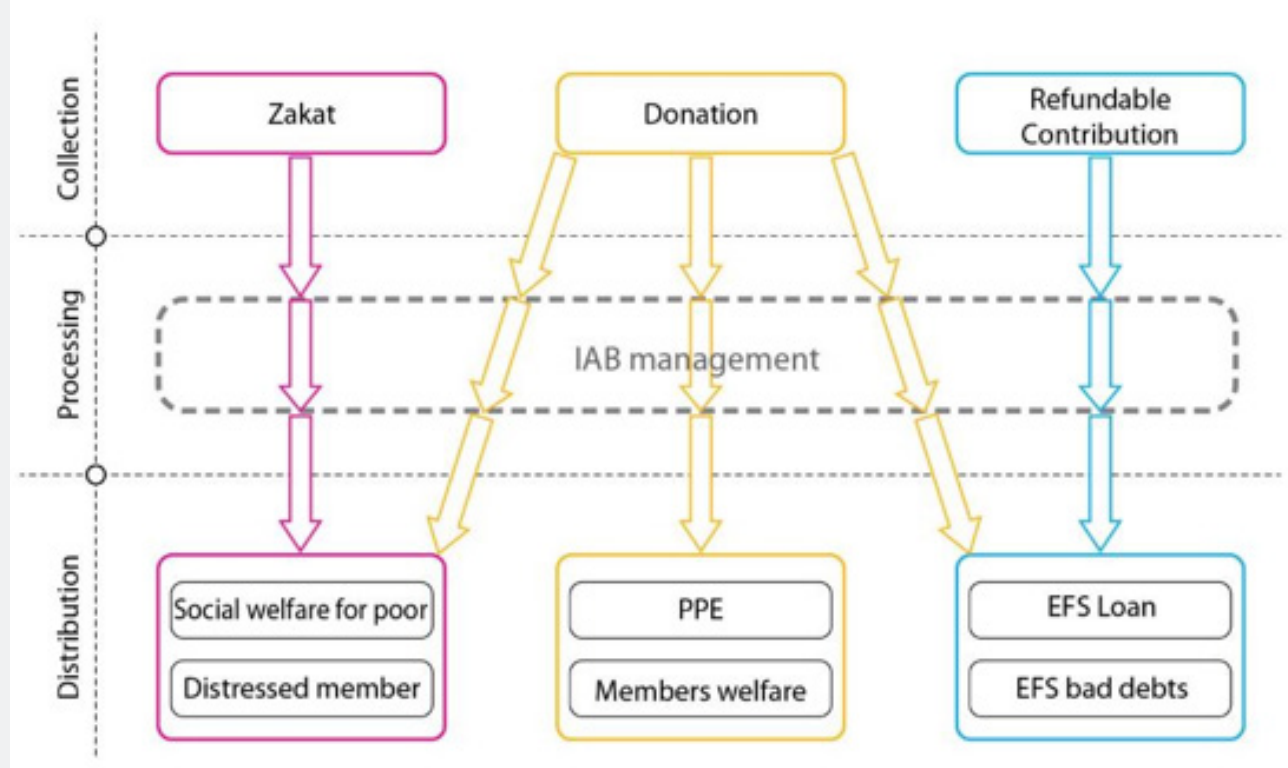

Figure 2: Source and distribution of funds for the COVID-19 crisis program.

\section{Step 2: Selection of Beneficiaries}

There can be two types of beneficiaries, individual and firm/ practice. Any regular IAB member (Associate Member, Member or Fellow) distressed by the COVID-19 crisis could apply for a loan to the EFS Board of Management through the proper application process and by submitting other required documents. With other supporting documents, an applicant had to submit a 'Letter of Recommendation' on the official letterhead from his/her current employer/ immediate past employer or from the Head of the department of his/her graduating school who must be an IAB member/fellow.

EFS Board of Management (EFS Board) would assess each application scrutinizing the documents submitted by the applicant, the records that IAB has and any other way it deems as suitable. There would be a Guarantor who shall be a regular IAB Member or Fellow for each applicant. The Guarantor would be liable to repay the loan in case the Beneficiary becomes a defaulter. One person cannot be a Guarantor for more than 3 (three) Beneficiaries.
The applicant might face an interview before the EFS Board. The interview might be held online. One member could apply once within this scheme.

On the other hand, any Architectural practice run by a regular IAB Member or Fellow could apply for a loan to pay the salary of its employee(s) who is/are regular IAB member (Associate Member, Member or Fellow) to the EFS Board of Management through the proper application process and by submitting other required documents.

Practice/Firm could apply for the loan to pay partial salary for a maximum of 3 employee architects. With other supporting documents, applicant practice had to submit the CVs of the employees it sought a loan for, proof of their latest salary structure and a bank statement of the official account. EFS Board would assess each application scrutinizing the documents submitted by the applicant, the records that IAB has and any other way it deems as suitable. 
The applicant must be the owner/ head of the practice. There would be a Guarantor who shall be a regular IAB Member or Fellow for each applicant. The Guarantor would be liable to repay the loan in case the Beneficiary becomes a defaulter. One person could not be a Guarantor for multiple applicants. The applicant might face an interview before the EFS Board. The interview might be held online. One Practice/ Firm could apply once within this scheme.

\section{Step 3: Disbursement of Fund}

For an individual applicant, the amount of loan would be a minimum of 50,000.00 BDT and a maximum of 200,000.00 BDT as per recommendations of the EFS Board and approved by the Executive Council of IAB. The sanctioned amount would be distributed to the beneficiary in five numbers of installments. The amount would be given to the Beneficiary as 'Loan', which shall have to be repaid without any profit for the Contributor.

The Beneficiary had to deposit five numbers of post-dated Cheques of his/her regular bank account in favor of IAB, in total which is equal to the full amount sanctioned for him/her. The dates of the cheques are the scheduled time of the EMI of repayment. These would be preserved as a security of the loan and shall be returned to the beneficiary after the full repayment of the loan. IAB has the right to place these cheques in case the beneficiary will be a defaulter. The applicant had to deposit his/her Original Membership Certificate at IAB. It will be returned after the full repayment of the loan. There would be a tri-party agreement between IAB, the Beneficiary and the Guarantor on non-judicial stamp mentioning the pay-off policy. Figure 3 shows the flowchart of the process of availing loan from the scheme.

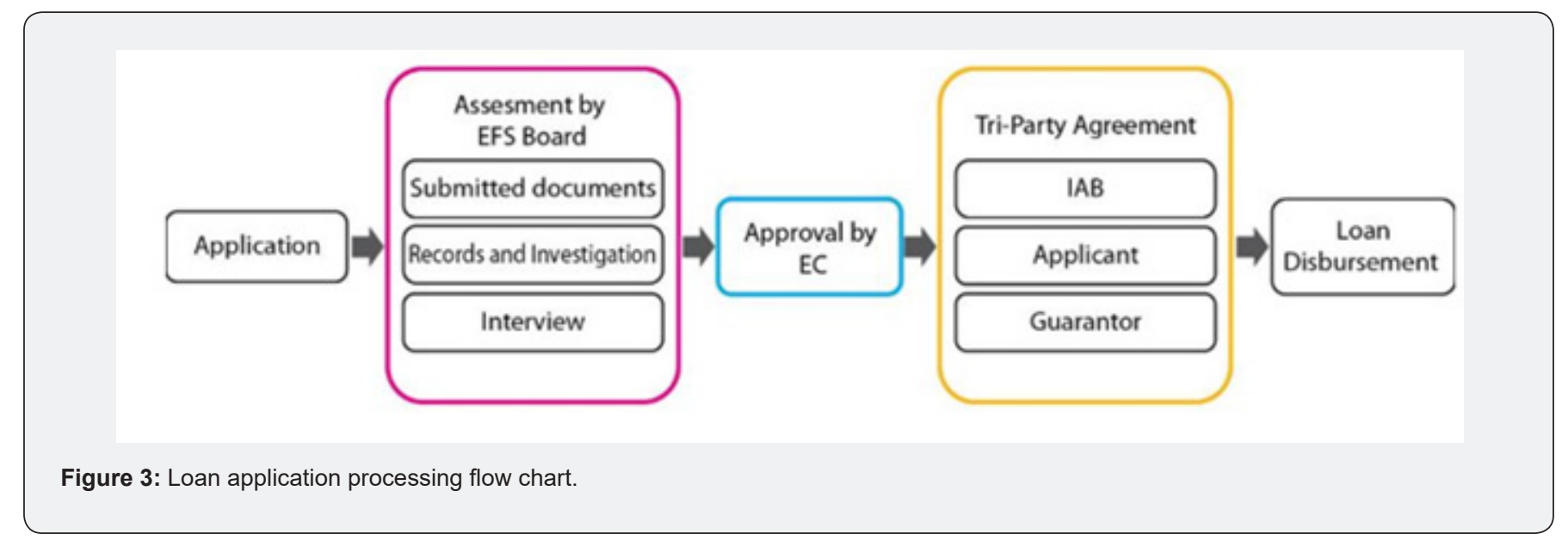

For a firm or practice, the amount of loan would be a minimum of 50,000.00 BDT and a maximum of 75,000.00 BDT for each employee as per recommendations of the EFS Board and approved by the Executive Council of IAB. The sanctioned amount would be distributed to the beneficiary in five installments i.e. 10,000 BDT to $15,000 \mathrm{BDT}$ per month as a part of their salary. The rest of the amount of his/her salary would be paid by the Employer.

The amount would be paid directly to the employee(s) account (bank/ mobile) of the practice and the amount would be given as a 'Loan' to the practice, which would have to be repaid without any profit to IAB. The beneficiary Practice/Firm had to deposit five numbers of post-dated Cheques of its official bank account in favor of IAB, in total which is equal to the full amount sanctioned. The dates of the cheques are the scheduled time of the EMI of repayment. These would be preserved as a security of the loan and shall be returned to the beneficiary after the full repayment of the loan. IAB has the right to place these cheques in case the beneficiary will be a defaulter to repay. The applicant had to deposit his/her Original Membership Certificate at IAB. It will be returned after the full repayment of the loan. There would be a tri-party agreement between IAB, the Beneficiary and the
Guarantor on non-judicial stamp mentioning the pay-off policy. The individual employees for whom the loan is taken are the witness of the agreement.

\section{Step 4: Repayment}

The repayment of an individual beneficiary would be started after eight (08) months from the date of receiving the first installment of the loan from IAB. The beneficiary will get a minimum of 5 months and maximum of 10 months to repay the total amount.

The total repayable loan amount would be distributed into 5 to 10 Equal Monthly Installments (EMI) (fixed by the EFS Board) and the beneficiary will pay it monthly. An individual beneficiary can make advance repayments or repay the full amount any time before the stipulated time. After the complete repayment of loan, IAB will issue clearance letters to both the individual beneficiary and guarantor (Figure 4).

The repayment of a firm/practice would be started after eight (08) months from the date of receiving the first installment of the loan from IAB. The Beneficiary will get a period of 5 to 10 months (fixed by the EFS Board) to repay the total amount. 


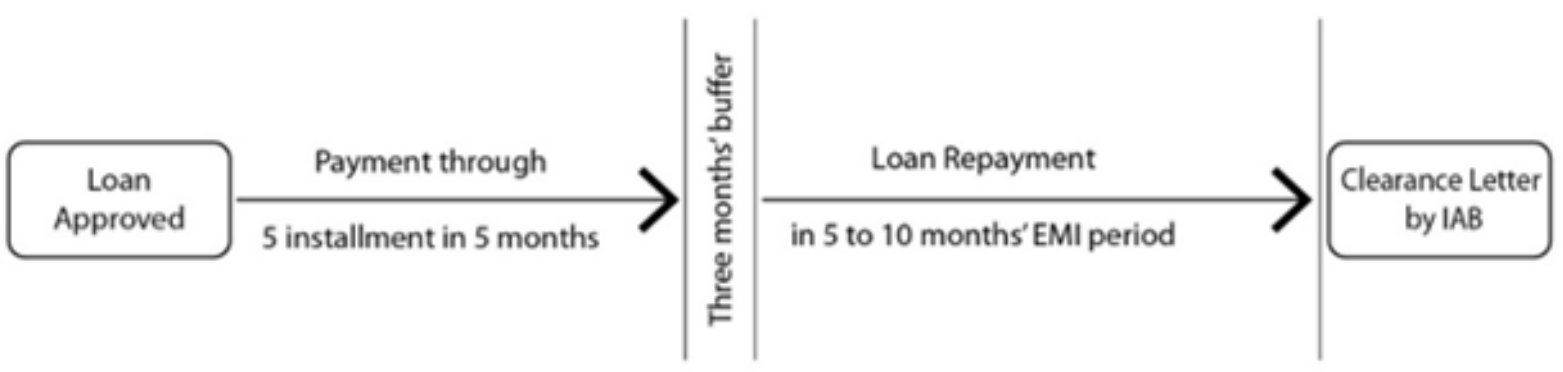

Figure 4: Loan Pay-off period for an individual.

The total repayable loan amount would be distributed into a 5 to 10 number (fixed by the EFS Board) Equal Monthly Installments (EMI) and the Beneficiary will pay it monthly. If any of the employees (for whom the loan was sanctioned) quit the job, the employer has to inform IAB in written to immediately stop the payment. The beneficiary can make advance repayments or repay the full amount any time before the stipulated time. After the complete repayment of the loan, IAB will issue clearance letters to the Beneficiary (Figure 5) (Table 1).

Table 1: Summary of the scheme.

\begin{tabular}{|c|c|c|}
\hline & Module A: Individual & Module B: Firm/ Practice \\
\hline Eligibility & Associate Member, Member or Fellow & Practice run by IAB Member or Fellow \\
\hline Required documents & $\begin{array}{l}\text { - } \quad \text { CV of the Applicant } \\
\text { - } \quad \text { Proof of appointment for job holder } \\
\text { Proof of present/last salary/payment amount } \\
\text { - } \quad \text { Trade license (if self-employed) } \\
\text { - } \quad \text { Bank statement or credit card bill statement } \\
\text { - } \\
\text { - } \\
\text { - } \\
\text { Phopy of NID of both applicant and Guarantor } \\
\text { (b) in Working of both applicant and Guarantor } \\
\text { (becommendation as described in } 2.1\end{array}$ & $\begin{array}{l}\text { - } \quad \text { Portfolio of the Firm/Practice } \\
\text { - } \text { Seeking for each employee for whom the Loan is } \\
\text { - Trade license } \\
\text { - Copy of Company Memorandum/ partnership } \\
\text { agreement } \\
\text { - } \quad \text { Bank statement } \\
\text { - Copy of NID of both Applicant and Guarantor } \\
\text { - } \quad \text { Loan is seeking for } \\
\text { Photographs of both Applicant and Guarantor } \\
\text { Photographs of each employee for whom the } \\
\text { Loan is seeking for }\end{array}$ \\
\hline Guarantor & IAB Member or Fellow & $\begin{array}{l}\text { IAB Member or Fellow } \\
\text { Other than Owner (in person) }\end{array}$ \\
\hline Beneficiary & One person & 1-3 persons of a Firm \\
\hline Amount & 50,000 to $2,00,000$ & $\begin{array}{l}50,000 \text { to } 75,000 \text { per person } \\
\text { (X } 3 \text { persons maximum) } \\
\text { Total: } 1,50,000 \text { to } 2,25,000\end{array}$ \\
\hline Distribution period & 5 months & 5 months (EMI) \\
\hline Mortgage & Cheques, Membership certificate & Cheques, Membership certificates \\
\hline Agreement type & Tri-party & Tri-party \\
\hline Buffer period & 3 months & 3 months \\
\hline Repayment starts & After 8 months & After 8 months \\
\hline Repayment duration & 5 - 10 months (EMI) & 5-10 months (EMI) \\
\hline $\begin{array}{l}\text { Approximate Duration of } \\
\text { scheme }\end{array}$ & 13 to 17 months & 13 to 17 months \\
\hline
\end{tabular}




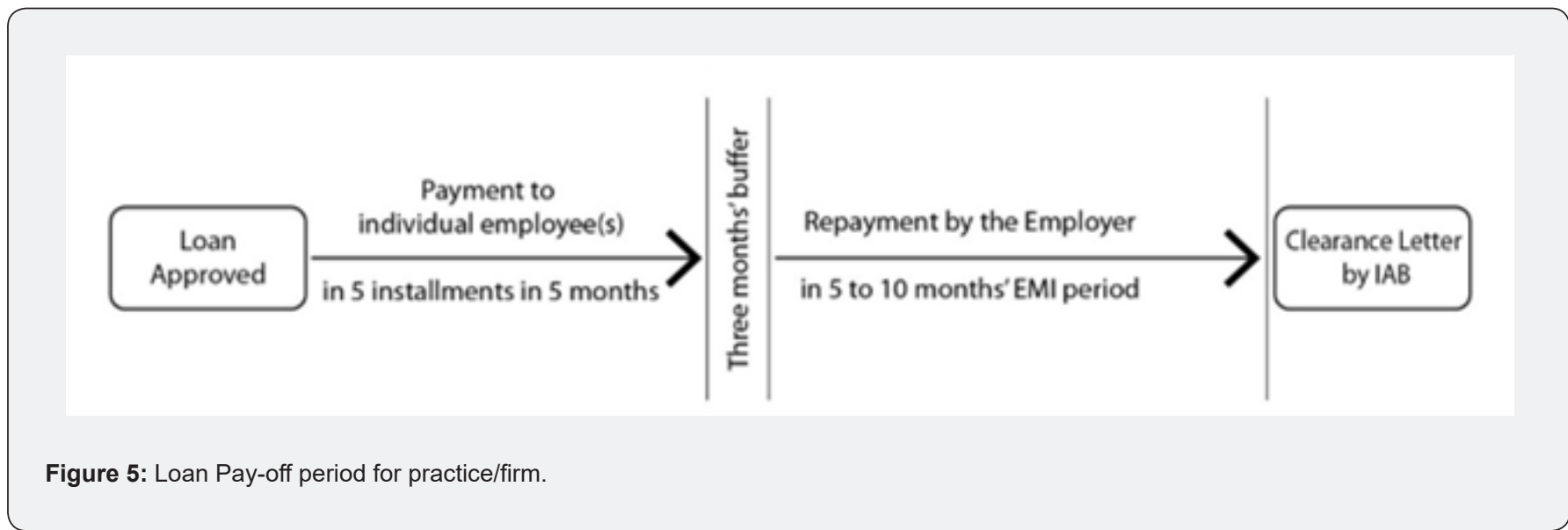

The following table shows the summary of the Emergency Financial Scheme (EFS):

\section{Defaulter}

The Beneficiary will be considered as 'Defaulter' if he/she fails to pay three consecutive EMIs. In such a case, the Guarantor has to make the Beneficiary pay the due amount or pay it on his/her own within the next three months (90 days) from the date of receiving a notice from IAB (through mail or E-mail). If the Guarantor or the Beneficiary fails to pay the dues within this 3 month stipulated period, the Guarantor will be considered as 'Defaulter' along with the Beneficiary.

IAB membership may be 'suspended' for anyone who is considered as a 'defaulter' and his/her signatory power in every building approval authority may also be suspended. He/she will not be allowed to participate in any IAB events or activities. The suspension period will be continued till all the loans will be duly paid.

If a Beneficiary fails to repay the loan within the stipulated time and becomes a Defaulter, then he/she will be bound to sign an agreement with IAB pledging that IAB shall have to be accepted as a Witness in all professional contracts for architectural design services that he/she will sign with clients till the loan is repaid and in the contracts it will be clearly stated that client shall issue cheques in favor of IAB equivalent to the unpaid loan amount, failing which IAB shall suspend the membership of the Beneficiary. In the case where the Beneficiary is in employment or will join as an employee in the future, the architect employer shall issue cheques in favor of IAB equivalent to the unpaid loan amount, failing which IAB shall suspend the membership of the employer. IAB shall have the right to publish the name of the defaulting Beneficiary if the EFS Board of Management recommends so.

\section{EFS Board of Management}

A Seven (07) member Board of Management would act as the authority of management and maintenance of the scheme. The Executive Council of IAB would appoint all the members of the Board for a period till December 2022. A senior Fellow of IAB who is not acting as a member of Executive Member shall be the Chairperson of the Board and Treasurer of IAB would act as the Member Secretary. The President of IAB would be the Deputy Chairman and IPP would be a member of the Board. The other three members would not be acting as members of the Executive Council, among them at least One Member would be a Fellow of IAB and one would be a Member of IAB.

The quorum for the meeting of the EFS Board is Four (4). Meetings might be held on the online platform. And decisions would be taken upon the majority of the board. All members would act as volunteers and he/she would not claim any remuneration for his/her service for the scheme.

Executive Council of IAB has the right to remove any Member of the Board if the majority of members of the Board so recommends. If the tenure of any member of the Executive Council expires, the new EC member of the same post shall replace him/her. If any member of the Board resigns or passes away during its tenure, Executive Council shall nominate a new Member for the remaining part of the Board's tenure. The board can recommend to EC for any sub-committee required to work the scheme smoothly and EC will form this according to the Constitutes of IAB.

The Board would consider each application without fear or favor and shall exercise honesty and fairness when assessing, accepting and rejecting applications. The budget for the EFS was fixed by the Executive Council and the EFS Board shall run the scheme within this budget. The Board shall recommend the name(s) of the selected beneficiaries to the Executive Council for final approval and the Executive Council would look after the necessary arrangement for disbursement. The Board would take needful initiatives and give suggestions to the Executive Council to ensure the repayment smoothly. EFS board can co-opt a maximum of two members with the approval of the Executive Council.

\section{Analysis and Findings}

To generate funds, an open Expression of Interest (EOI) was invited to all the members of IAB through email. Total 25 contributors contributed a total amount of 8,950,000 BDT (86 BDT 
= 1 USD) for EFS fund. Among them, 23 are individual architects who have contributed 7,450,000 BDT and two practicing firms have contributed an amount of 1,500,000 BDT. The minimum contribution was $50,000 \mathrm{BDT}$ and the maximum was $2,000,000$ BDT. According to the system of EFS, all the contributions are refundable and free from any sort of interest.

A total of 16 individual architects applied and were granted a loan from EFS. No one applied for a loan in the firm/practice category. Among the 16 beneficiaries, $50 \%$ is associate members and $50 \%$ is member of IAB. The name and identity of the beneficiaries are kept in secret from the general members.

There is only three female among the 16 beneficiaries and all of them are associate members which indicate that they are young professionals. The following chart shows that $81 \%$ of beneficiaries are male (Figure 6).

$43.8 \%$ of beneficiaries are of the age group of 31-35 years. And $18.8 \%$ from $36-40$ years. $75 \%$ of the beneficiaries are below 40 years old (Figure 7). That shows that young architects need this emergency financial help most.

Figure 6: Ratio of beneficiaries based on gender.
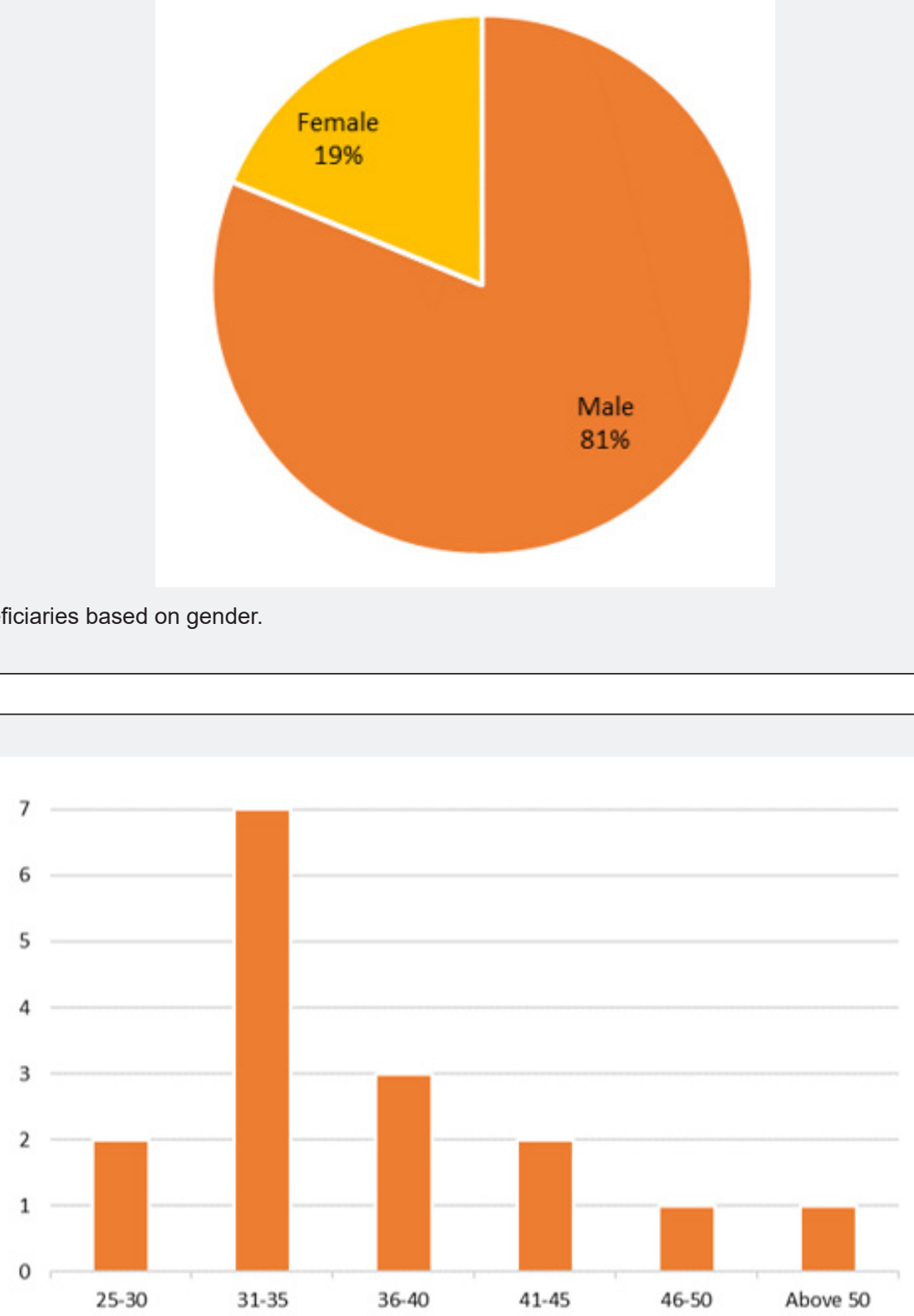

Figure 7: Beneficiaries age group. 
Both the entrepreneur and employee architects are in a financial crisis due to COVID-19. 50\% of the beneficiaries are the entrepreneur or owner of own practice and $50 \%$ are an employee of any firm or corporate house (Figure 8).
13 beneficiaries which is $81 \%$ of total beneficiaries are found married and 3 which is $19 \%$ of the total are found unmarried (Figure 9).

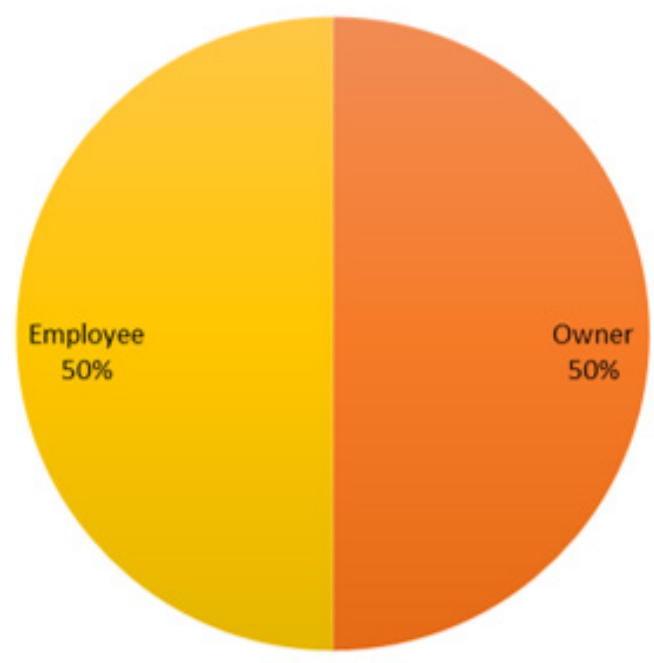

Figure 8: Ratio of beneficiaries based on their ownership type.

Figure 9: Ratio of beneficiaries based on their marital status.

Among the 13 beneficiaries who are married, 4 have no child, 4 have one child and 5 have 2 children. This indicates that more family members create more financial overhead (Figure 10).

Besides spouse and kids, beneficiaries have to support additional members of their families. there are 14 beneficiaries found who have to make financial support for their parents and five beneficiaries found who have to do it for siblings. Among them, four beneficiaries have to make support for both their parents and siblings (Figure 11).

Three of the beneficiaries had a regular monthly income of less than 20 thousand taka, four had between 30 to 30 thousand taka, two had between 30 to 40 thousand taka, another two had 
between 40 to 50 thousand taka, three had between 50 to 109 thousand taka and two had above 100 thousand taka. The monthly regular income of $68.8 \%$ of beneficiaries is below 50 thousand taka (Figure 12).

A member can avail interest-free loan from the scheme of a minimum of BDT 50,000 to a maximum of BDT 2,00,000. Among the beneficiaries only one is sanctioned for an amount of 100,000
BDT; two architects are sanctioned for an amount of 150,000 BDT and 13 are sanctioned for 200,000 BDT (Figure 13).

A total of 2,950,000 BDT was disbursed as a short-term loan to the architects among the 16 beneficiaries which is only $33 \%$ of the total fund (Figure 14). Rest $67 \%$ of the fund remains unutilized and there is a probability to call for application among the members again.

Figure 10: Ratio of beneficiaries based on the number of children.
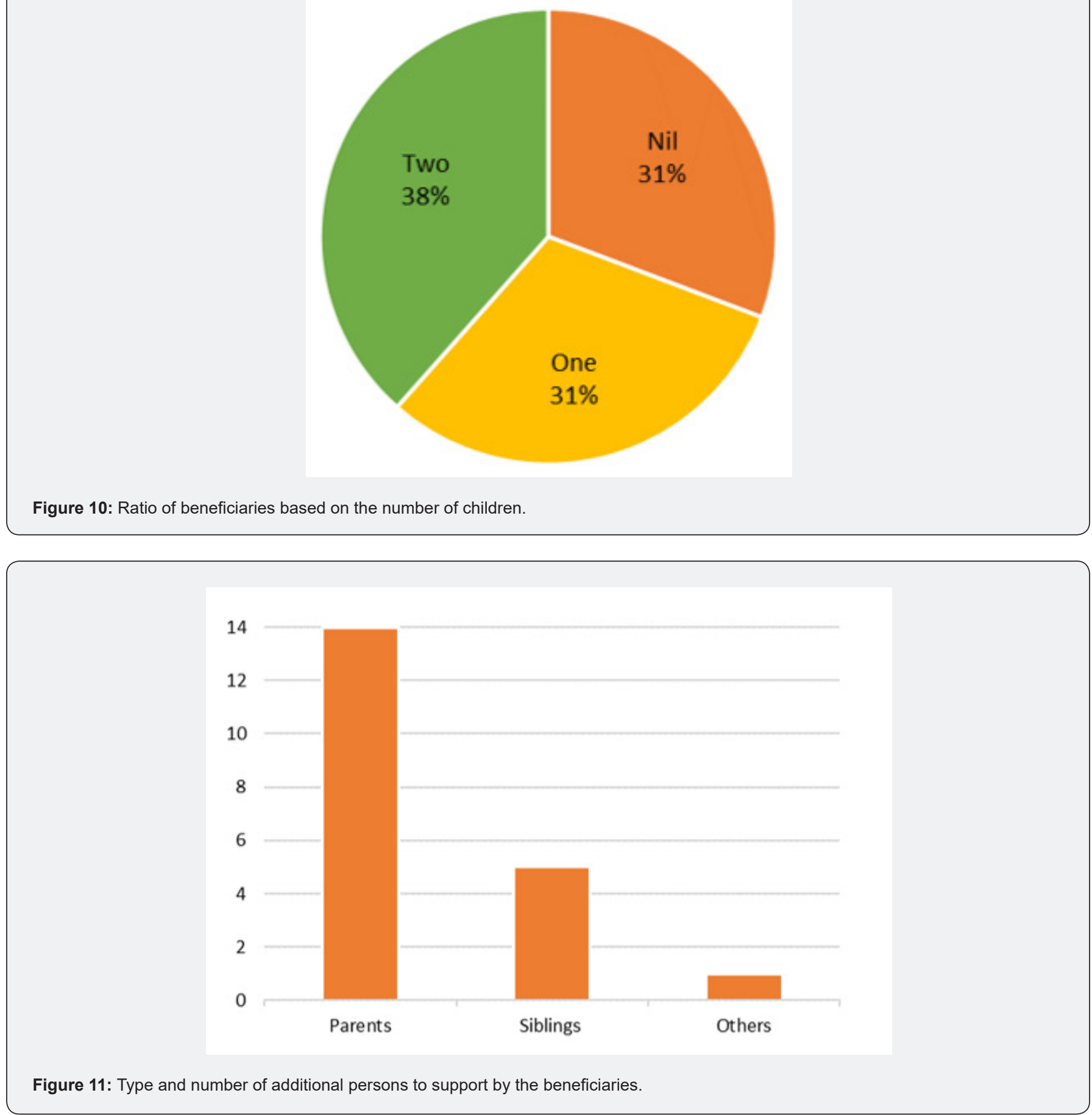
Annals of Social Sciences \& Management studies

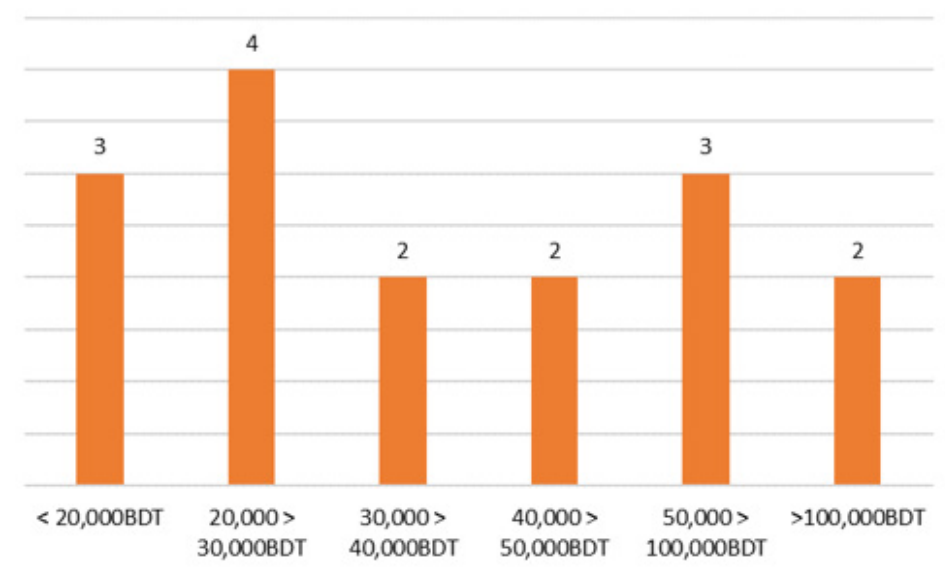

Figure 12: Number of the beneficiaries according to their income range.

Figure 13: Ratio of beneficiaries based on their loan amount.

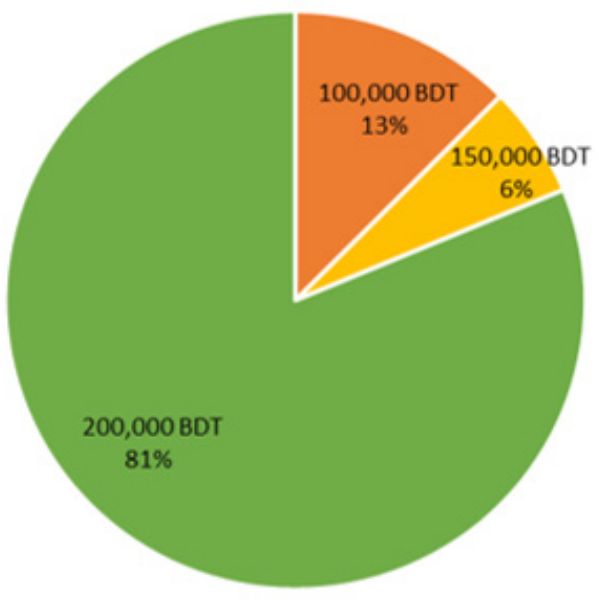

Figure 13: Ratio of beneficiailes based on their loan amount.

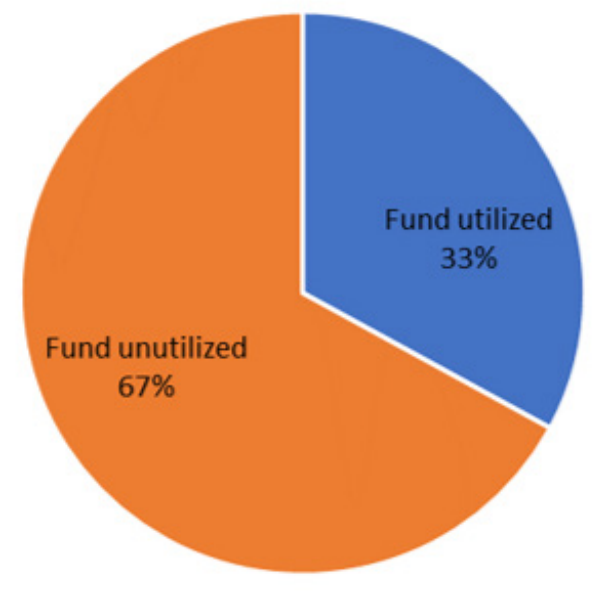

Figure 14: Ratio of the utilization of total funds for the scheme. 


\section{Conclusion}

EFS program is the first of its kind. This financial scheme provides an interest-free loan to the architects who are distressed by the COVID-19 pandemic. The beneficiaries would not pay any extra amount other than the amount they have taken as a loan. The documentation cost would be bearable by the IAB. This is a scheme where well-off architects of the community are helping without any profit. They are doing it as their social responsibility.

According to the survey among the beneficiaries, $68.8 \%$ of them have own practice but not receiving payment from clients. $25 \%$ are continuing their job with a partial salary. $17.4 \%$ have lost their job due to COVID-19 crisis. It shows that most of the architects have their own practice on a various scale whether they are an employee of a firm or in a corporate company.

It is found by this study that male architects below 40 years of age are in need of this loan much. This group has a monthly income of less than 50 thousand taka, married and having kids and is obliged to support their parents. This indicates that they are the most distressed group in terms of financial crisis due to the COVID-19 pandemic.

It is found that only $33 \%$ of the total fund is utilized for the purpose. The reasons behind it can be as follows:

i. The amount of the loan is 50 thousand to 200 thousand taka only. Which may not be an attractive amount for these professionals.

ii. Most of the Architects may have alternative financial support or source to survive during the pandemic.

iii. Architects may be afraid to be failed in repayment. As their failure to repay would be a cause of losing their license to practice, they feel it risky.

iv. Architects may think that taking a loan from IAB is a matter of social dignity.

If the above points are addressed carefully in the future the EFS can be more helpful and well accepted for the architects. The module of EFS can be adopted by other professional institutes also.

\section{References}

1. Hellweg R, Cano O, Hellweg C (2020) Deep analysis of the COVID-19 pandemic: A complex interaction of scientific, political, economic and psychological facts and fakes.

2. Pazarbasioglu C, Kose MA (2020) Unprecedented damage by COVID-19 requires an unprecedented policy response. Brookings.

3. Haleem A, Javaid M, Vaishya R (2020) Effects of COVID-19 pandemic in daily life. Current Medicine Research and Practice10(2): 78-79.

4. Chinazzi M, Davis JT, Ajelli M, Gioannini C, Litvinova M, et al. (2020) The effect of travel restrictions on the spread of the 2019 novel coronavirus (COVID-19) outbreak. Science 368(6489): 395-400.

5. Bodrud-Doza M, Shammi M, Bahlman L, Islam ARM T, Rahman MM (2020) Psychosocial and Socio-Economic Crisis in Bangladesh Due to COVID-19 Pandemic: A Perception-Based Assessment. Frontiers in Public Health 8: 341.

6. IAB- Institute of Architects Bangladesh (2018) IAB Retrospect 2017 2018, Institute of Architects Bangladesh, 2018.

7. IAB- Institute of Architects Bangladesh (2021) IAB website, www.iab. com.bd.

8. GoB- Government of Bangladesh (2008) Dhaka Mohanagar Imarat Nirman Bidhimala 2008, Ministry of Housing and Public Works.

9. IAB- Institute of Architects Bangladesh (2020) Working Paper on Emergency Finance Scheme (EFS) for IAB Members.

\begin{tabular}{|l|}
\hline \multicolumn{1}{|c|}{ Your next submission with Juniper Publishers } \\
will reach you the below assets \\
- Quality Editorial service \\
- Swift Peer Review \\
- Reprints availability \\
- E-prints Service \\
- Manuscript Podcast for convenient understanding \\
- Global attainment for your research \\
- Manuscript accessibility in different formats \\
( Pdf, E-pub, Full Text, Audio) \\
- Unceasing customer service \\
Track the below URL for one-step submission \\
https://juniperpublishers.com/online-submission.php \\
\hline
\end{tabular}

